\title{
Use of nutritional food labels and consumers' confidence in label information
}

\author{
Uso da rotulagem nutricional e percepção \\ sobre a confiabilidade das informações \\ por consumidores
}

\author{
Lisane Moreno Lorena de SOUSA ${ }^{1}$ (ID) 0000-0001-9206-3364 \\ Lize STANGARLIN-FIORI² (D) 0000-0001-7904-904X \\ Esther Heyde Selke COSTA 1 (D) 0000-0001-7456-0711 \\ Fernanda FURTADO ${ }^{1}$ (ID) 0000-0001-8858-6074 \\ Caroline Opolski MEDEIROS ${ }^{1}$ (D) 0000-0001-7299-9149
}

\section{A B S T R A C T}

\section{Objective}

This investigation evaluated the use of food labels and consumers' perception of the reliability of food labels nutritional information.

\section{Methods}

This is a transversal exploratory quantitative investigation, carried out in Curitiba, Brazil. A total of 536 students from a public institution participated in the survey answering a structured questionnaire. Descriptive analyses, Chi-Square test and Fisher's exact test were performed considering a significance level of $5 \%$.

\section{Results}

The participants' mean age was $21.11 \pm 2.83$ years, and $59.3 \%$ were female. It was noticed that $41.6 \%$ of consumers used the nutritional information sometimes and $14.7 \%$ always, mainly because they liked to know what they were buying and consuming (35.8\%). Lack of patience $(29.5 \%)$ and concern about the composition of the food purchased $(34.2 \%)$ were the main reasons for not using the information provided. The most

\footnotetext{
1 Universidade Federal do Paraná, Setor de Ciências da Saúde, Departamento de Nutrição. Av. Pref. Lothário Meissner n. 632, Jardim Botânico, 80210-170, Curitiba, PR, Brasil. Correspondence to: CO MEDEIROS. E-mail: <caroline.opolski@gmail.com>.

2 Universidade Federal do Paraná, Departamento de Nutrição, Programa de Pós-Graduação em Alimentação e Nutrição. Curitiba, PR, Brasil.
}

\section{How to cite this article}

Sousa LML, Stangarlin-Fiori L, Costa EHS, Furtado F, Medeiros CO. Use of nutritional food labels and consumers' confidence in label information. Rev Nutr. 2020;33:e190199. https://doi.org/10.1590/1678-9865202033e190199 
commonly used nutrition claim was "trans fat-free" (42.5\%) and the type of food in which nutrition labeling was used most was milk and dairy products (42.0\%). Frequent use of nutritional information was higher among women $(p<0.01)$ and among those who practice physical activity $(p=0.04)$. Many individuals relied on food labels nutritional information (61.9\%), but out of these, $43.6 \%$ did not use that information at the time of purchase. There was no difference between respondents' confidence in the information, sociodemographic and health data.

\section{Conclusion}

Many people still do not use the label nutrition information. Efforts should be made to change this scenario. Changes in nutrition labeling can help modify this situation, with the use of clearer label information, more easily understood, that does not raise any doubts in the consumers' mind.

Keywords: Functional claim. Nutritional facts. Nutritional labeling. Young adult.

\section{RE S U M O}

\section{Objetivo}

Este estudo avaliou o uso da rotulagem nutricional e a percepção sobre a confiabilidade das informações por consumidores.

\section{Métodos}

Pesquisa transversal, exploratória e de abordagem quantitativa, realizada no município de Curitiba, Brasil. Participaram 536 estudantes, de uma instituição pública, respondendo um questionário estruturado. Foram realizadas análises descritivas, teste Qui-Quadrado e teste exato de Fisher, considerando nível de significância de $5 \%$.

\section{Resultados}

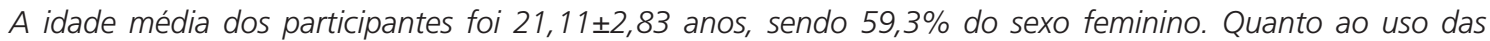
informações nutricionais, 41,6\% utilizavam às vezes e 14,7\% sempre, principalmente porque gostavam de saber o que estavam comprando e consumindo (35,8\%). A falta de paciência (29,5\%) e de preocupação com a composição do alimento comprado (34,2\%) foram os principais motivos pelos quais não utilizarem as informações. A alegação nutricional mais utilizada foi "sem gordura trans" (42,5\%) e o tipo de alimento em que mais se utilizou a rotulagem nutricional foi leite e derivados $(42,0 \%)$. O uso frequente das informações nutricionais foi maior entre as mulheres $(p<0,01)$ e os praticantes de atividade física $(p=0,04)$. Muitos indivíduos confiavam nas informações presentes nos rótulos dos alimentos (61,9\%), porém, destes, 43,6\% não as utilizavam no momento da compra. Não foram observadas diferenças entre a confiança das informações, os dados sociodemográficos ou de saúde dos entrevistados.

\section{Conclusão}

Muitas pessoas ainda não usam as informações nutricionais, sendo necessário esforços para mudar este panorama. Alterações na rotulagem nutricional podem mudar este processo, com o uso de informações mais claras, de fácil entendimento, que não gerem dúvida ao consumidor.

Palavras-chave: Alegação de propriedades funcionais. Informação nutricional. Rotulagem de alimentos. Adulto jovem.

\section{NTRODUCTION}

People seek convenience at all times in their life, especially at mealtimes, thus causing a great demand for ready-to-eat foods that offer a longer shelf life and shorter preparation time $[1,2]$. In response to this demand, the offer of processed and ultra-processed products is increasing on supermarket shelves. However, the consumption of these foods has been associated with an increased incidence of obesity, as well as with chronic non-communicable diseases [2-5].

In this context, it is essential that consumers have access to the nutritional information of these products, in order to exercise their right of choice; this right is ensured in different countries 
(e.g.: Brazil, Chile) $[6,7]$ and by international bodies [8]. Thus, food labeling outstands in this scenario, since it is the main mean of communication between the manufacturer and the consumer about the nutritional properties and components of a food [8]. It is through the label that the consumer has access to information about the nutritional properties of a food, including its ingredients, the energy value claim and the main nutrients available $[9,10]$.

Studies demonstrate that the information provided on food labels can influence consumer's choices [11-13], and this information can contribute to more conscious choices, and help in the prevention of diseases and in the well-being of the population [12,14-18]. However, making the nutritional information of the products available to the consumer, through labeling, does not guarantee its use. International studies demonstrate that the use of food labels nutritional information can be related to the socioeconomic level $[17,19-21]$, educational level $[21,22]$, work activity [14], gender $[12,14]$ and eating behavior of the consumers [12]. In addition, its use can be influenced by the way the information is exhibited on the label $[15,20,21,23,24]$.

In South America, the concern with conscious use of nutrition labeling has been prominent in recent years. In Chile, the government verified the need to change the format of the nutritional information on the label, guaranteeing the population's right to know what they are consuming [7,24]; the same occurred in Peru [25] and in Uruguay [26].

In Brazil, a new proposal for nutritional labeling has also been advocated by professionals, entities and organizations [27-30], favoring policies that allow choosing better foods for health [31]. However, food labeling changes have not yet taken place, although in Brazil research on the understanding and influence of label nutrition information on food purchasing intention has been set as one of the research priorities for the management of the Politica Nacional de Alimentação e Nutrição (PNAN, National Food and Nutrition Policy) [31].

At a time when changes are being discussed in the way nutrition labeling is made available in Brazil and based on research priorities set forth by the PNAN management, the importance of understanding the factors that influence the use of nutritional information by consumers stands out. Therefore, and considering the importance of nutrition labeling in food selection, the objective of this study was to evaluate the use of nutrition labeling by adult consumers and their perception of the reliability of the label information.

\section{METHOD S}

The present work comprises a field cross-sectional, exploratory and quantitative research, approved by the Ethics Research Committee (REC) of the Federal University of Paraná (REC Opinion No.1294619), and carried out at a public university in the city of Curitiba, Brazil, in the year 2018.

The population was composed of university students. The sample was calculated considering the number of students enrolled, according to the last available university report (2016 year report) before data collection ( $\mathrm{N}=18,698), 95 \%$ confidence level, $5 \%$ margin of error and an unknown prevalence of $50.00 \%$, resulting in a sample of at least 377 individuals. The sample was calculated using the public program OpenEpi, version 3.01 [32]. A total of 536 consumers participated in the survey, exceeding the sample calculation and resulting in a margin of error of $4.17 \%$, lower than that initially estimated. 
The investigation inclusion criteria were: be over 18 years of age; buy food, even if occasionally; be a student at the university where the survey was conducted; and accept to participate in the investigation by signing the Free and Informed Consent Form.

A questionnaire was prepared based on an integrative review carried out in 2016, in the databases of the Scientific Electronic Library Online (SciELO), Scopus, National Library of Medicine (PubMed), Latin American \& Caribbean Health Sciences Literature (LILACS), Cochrane Library, and Food Science and Technology Abstracts (FSTA).

To search for articles the following combination of keywords was used: "Adult OR Young Adult OR Consumer Behavior OR Consumer Health Information" AND "Product Labeling; Nutritional Labeling; Food Labeling; Nutritional Facts" AND "Utilization OR Reading OR Comprehension" AND "Food Consumption OR Eating OR Diet OR Food and Nutrition OR Food OR Food Preferences OR Food Habits OR Diet OR Feeding Behavior".

After searching the databases, the articles were selected considering the inclusion criteria: (a) be an original article; (b) the target audience be adult consumers; (c) be published in Portuguese or English; (d) addressing the use of nutritional information contained in food labels. After reading and reviewing the material, 10 articles were taken into account for the elaboration of the questionnaire [14-17, 19-23,33], besides the current Brazilian legislation $[9,10]$.

The questionnaire was composed of three parts: (1) sociodemographic data: age, gender, income, student's course and region where the student lives (urban or rural); (2) use of nutritional information: factors that influenced the interviewee at the time of purchase; search for nutritional information; use of information provided on labels; reasons for using (or not) the nutritional information; important nutritional information for the selection of products; use of the products nutritional claims; confidence in the nutritional information (and the reasons for mistrust); types of food that uses nutritional information; format of nutritional information; (3) nutritional status and health of the respondent: self-reported weight and height, frequency of physical activity and presence or absence of illness or food restriction. Most of the questions were closed questions, and the questions that investigated the age, students' course, reasons for not trusting the nutritional information, the self-reported weight and height were open-ended questions. The questions and their alternatives (closed questions) were elaborated based on the integrative review.

From October to December 2017, a pre-test was carried out with 40 individuals, with the same characteristics as the target audience, in order to assess the participants' understanding when answering the questionnaire, the adequacy of the questions for the target audience, the extent of the instrument, and the form of application of the instrument (face to face interview or self-report). After the pre-test, some questions were revised to be more objective, based on the participants' suggestions. In addition, both data collection formats (face-to-face or self-report) were well accepted by the participants and, therefore, were maintained.

Subsequently, data collection was carried out between March and June 2018. Consumers were courteously approached in the crowded common areas of the university. After approaching and explaining the survey objective, those who agreed to participate read and signed the informed consent form. Subsequently, consumers answered the survey questionnaire, through an interview using the face-to-face method or self-answering the questionnaire, according to the respondent's preference.

The analysis of data concerning lack of confidence in the food label nutrition information, was carried out by two independent surveyors who compiled similar information, after the transcription 
of the participants' responses. Subsequently, similar responses were clustered into the same category. Consumers' mentions in each category were counted so that it would be possible to visualize the most frequent ones, helping data discussion considering the numerous study participants. For this analysis, the technique described by Gagné \& Godin was considered [34].

The Body Mass Index (BMI) was calculated from the self-reported weight and height measurements. The individuals were classified as low weight (BMI $\leq 18.49 \mathrm{~kg} / \mathrm{m}^{2}$ ), eutrophic (BMI $\geq 18.50$ and $\leq 24.99 \mathrm{~kg} / \mathrm{m}^{2}$ ) and overweight (overweight and obesity) (BMI $\left.\geq 25.00 \mathrm{~kg} / \mathrm{m}^{2}\right)[35,36]$.

The data were tabulated with double entry and the analysis was performed using the Statistica software, version 7 (Tulsa, USA) [37]. The normality of continuous data was analyzed using the Shapiro Wilk test. Descriptive statistical analyses were performed, and the association between the outcome variables (use of nutritional information; confidence in nutritional information) and predictors (sociodemographic data, nutritional status, physical activity and health problems) was assessed using the Chi-Square test and Fisher's exact test. Furthermore, the variables on the use of nutritional information were analyzed as predictive variables with respect to the outcome variable confidence in nutritional information. Significance level was set at $5 \%$.

\section{R E S U L T S}

A total of 536 adult consumers participated in the survey; their average age was $21.11 \pm 2.83$ years, representing a minimum age of 18 and a maximum of 36 years. The sociodemographic data of the participants is shown in Table 1.

The factors that most influenced food purchase were price $(79.9 \%, n=428)$ and taste $(78.0 \%$, $\mathrm{n}=418$ ), with product ingredients influencing women more than men at the time of purchase $(44.7 \%$ and $24.8 \%$, respectively) ( $p<0.01)$. As for the use of nutritional information, the majority of respondents indicated they used it sometimes, with greater use among women $(p<0.01)$ (Table 2$)$.

The main justifications for not using the information were the lack of concern with the composition of the food they bought and for not having the patience to read. On the other hand, those who used it always or sometimes, reported being motivated because they liked to know what they were buying and consuming, as they liked to care for their health and had questions about food composition (Table 2).

Regarding the types of food, the use of nutritional information was more frequent when buying stuffed crackers and snacks, milk and dairy products, canned food and sausage. In the case of the purchase of milk and dairy products $(p=0.01)$, breads and toast $(p<0.01)$ and light and diet foods $(p<0.01)$ the use was greater among women. As for the place where they looked for nutritional information, the means of communication were the most reported, especially among women $(p<0.01)$ (Table 2).

The main claims used by the interviewees were "trans fat-free", followed by "source of vitamins and minerals" and "rich in fiber"/"fiber source", with greater use among women $(p<0.01)$, while men used claims less than women $(p<0.01)$ (Table 2$)$. When asked which nutritional information was most important when choosing the food, it was observed that the calorie information appeared at the top $(23.3 \%, n=123)$, followed by the list of ingredients $(22.6 \%, n=119)$, fat $(13.7 \%, n=72)$, vitamins $(12.5 \%, n=66)$; proteins $(10.7 \%, n=56)$, carbohydrates $(9.7 \%, n=51)$ and fibers $(4.4 \%$, $n=23)$. 
Table 1. Consumers sociodemographic and health data, according to gender, and the relationship with their confidence in the information presented on nutrition labeling. Curitiba (PR), Brazil, 2018.

\begin{tabular}{|c|c|c|c|c|c|c|c|c|c|c|c|c|c|}
\hline \multirow{3}{*}{ Variables } & \multicolumn{6}{|c|}{ Frequency $(n=536)$} & \multicolumn{7}{|c|}{$\begin{array}{l}\text { Confidence in the information presented on nutrition } \\
\text { labeling }\left(n=532^{1}\right)\end{array}$} \\
\hline & \multicolumn{2}{|c|}{$\begin{array}{c}\text { Total } \\
(n=536)\end{array}$} & \multicolumn{2}{|c|}{$\begin{array}{c}\text { Male } \\
(n=218)\end{array}$} & \multicolumn{2}{|c|}{$\begin{array}{l}\text { Female } \\
(n=318)\end{array}$} & \multicolumn{2}{|c|}{$\begin{array}{c}\text { Yes } \\
(n=332)\end{array}$} & \multicolumn{2}{|c|}{$\begin{array}{l}\text { Depends } \\
\text { on the food } \\
(n=143)\end{array}$} & \multicolumn{2}{|c|}{$\begin{array}{c}\text { No } \\
(n=57)\end{array}$} & \multirow[t]{2}{*}{$p$-value } \\
\hline & $n$ & $\%$ & $\mathrm{n}$ & $\%$ & $\mathrm{n}$ & $\%$ & $n$ & $\%$ & $n$ & $\%$ & $n$ & $\%$ & \\
\hline \multicolumn{14}{|l|}{ Gender } \\
\hline Female & 318 & 59.3 & & & & & 193 & 58.1 & 87 & 61.4 & 35 & 61.4 & \multirow{2}{*}{0.64} \\
\hline Male & 218 & 40.7 & & & & & 139 & 41.9 & 56 & 39.2 & 22 & 38.6 & \\
\hline \multicolumn{14}{|l|}{ Age } \\
\hline Up to 20 years & 218 & 40.7 & 100 & 45.9 & 180 & 56.6 & 178 & 53.6 & 74 & 51.7 & 27 & 47.4 & \multirow{2}{*}{0.38} \\
\hline $21-25$ years & 280 & 52.2 & 92 & 42.2 & 126 & 39.6 & 137 & 41.3 & 55 & 38.5 & 23 & 40.4 & \\
\hline$\geq 26$ years & 38 & 7.1 & 26 & 12.0 & 12 & 3.7 & 17 & 5.1 & 14 & 9.8 & 7 & 12.3 & - \\
\hline \multicolumn{14}{|l|}{ Respondent's sector of activity } \\
\hline Health Sciences Sector & 158 & 29.5 & 39 & 17.9 & 119 & 37.4 & 92 & 27.7 & 52 & 36.4 & 13 & 22.8 & \\
\hline Agrarian Sciences Sector & 102 & 19.0 & 48 & 22.0 & 54 & 17.0 & 76 & 22.9 & 19 & 13.3 & 7 & 12.3 & \\
\hline Human Sciences Sector & 81 & 15.1 & 36 & 16.5 & 45 & 14.2 & 48 & 14.5 & 22 & 15.4 & 11 & 19.3 & \\
\hline Social Sciences Sector & 71 & 13.2 & 38 & 17.4 & 33 & 10.4 & 46 & 13.9 & 18 & 12.6 & 7 & 12.3 & \\
\hline Biological Sciences Sector & 48 & 9.0 & 24 & 11.0 & 24 & 7.5 & 23 & 6.9 & 16 & 11.2 & 8 & 14.0 & \\
\hline $\begin{array}{l}\text { Arts. Communication and } \\
\text { Design Sector }\end{array}$ & 11 & 2.1 & 1 & 0.5 & 10 & 3.1 & 5 & 1.5 & 1 & 0.7 & 4 & 7.0 & \\
\hline Earth Sciences Sector & 7 & 1.3 & 5 & 2.3 & 2 & 0.6 & 6 & 1.8 & 1 & 0.7 & 0 & 0.0 & \\
\hline Legal Sciences Sector & 6 & 1.1 & 3 & 1.4 & 3 & 0.9 & 2 & 0.6 & 3 & 2.1 & 0 & 0.0 & \\
\hline $\begin{array}{l}\text { Professional and Techno- } \\
\text { logical Education Sector }\end{array}$ & 5 & 0.9 & 4 & 1.8 & 1 & 0.3 & 2 & 0.6 & 2 & 1.4 & 1 & 1.8 & \\
\hline Exact Sciences Sector & 3 & 0.6 & 2 & 0.9 & 1 & 0.3 & 3 & 0.9 & 0 & 0.0 & 0 & 0.0 & \\
\hline Education Sector & 2 & 0.4 & 0 & 0.0 & 2 & 0.6 & 2 & 0.6 & 0 & 0.0 & 0 & 0.0 & \\
\hline Other area & 38 & 7.1 & 15 & 6.9 & 23 & 7.2 & 23 & 6.9 & 9 & 6.3 & 6 & 10.5 & \\
\hline No reply & 4 & 0.7 & 3 & 1.4 & 1 & 0.3 & 4 & 1.2 & 0 & 0.0 & 0 & 0.0 & \\
\hline \multicolumn{14}{|l|}{ Income (MW) } \\
\hline Up to $3 \mathrm{MW}$ & 204 & 38.1 & 80 & 36.7 & 124 & 39.0 & 125 & 37.7 & 54 & 37.8 & 24 & 42.1 & \multirow{4}{*}{0.93} \\
\hline More than 3 to $10 \mathrm{MW}$ & 221 & 41.2 & 91 & 41.7 & 130 & 40.9 & 136 & 41.0 & 58 & 40.6 & 24 & 42.1 & \\
\hline More than 10MW & 61 & 11.4 & 29 & 13.3 & 32 & 10.1 & 37 & 11.1 & 19 & 13.3 & 5 & 8.8 & \\
\hline Not informed/No reply & 50 & 9.3 & 18 & 8.3 & 32 & 10.1 & 34 & 10.2 & 12 & 8.4 & 4 & 7.0 & \\
\hline \multicolumn{14}{|l|}{ Region where living } \\
\hline Urban & 524 & 97.8 & 213 & 97.7 & 311 & 97.8 & 322 & 97.0 & 142 & 99.3 & 56 & 98.2 & \multirow{4}{*}{0.50} \\
\hline Rural & 6 & 1.1 & 4 & 1.8 & 2 & 0.6 & 6 & 1.8 & 0 & 0.0 & 0 & 0.0 & \\
\hline Both & 1 & 0.2 & 0 & 0.0 & 1 & 0.3 & 0 & 0.0 & 0 & 0.0 & 1 & 1.8 & \\
\hline No reply & 5 & 0.9 & 1 & 0.5 & 4 & 1.3 & 4 & 1.2 & 1 & 0.7 & 0 & 0.0 & \\
\hline Nutritional Status| $\left.\right|^{2}$ & & & & & & & & & & & & & \\
\hline Eutrophic & 361 & 67.4 & 150 & 68.8 & 211 & 66.4 & 225 & 67.8 & 92 & 64.3 & 41 & 71.9 & \\
\hline Overweight & 115 & 21.5 & 56 & 25.7 & 59 & 18.6 & 62 & 18.7 & 40 & 28.0 & 13 & 22.8 & \\
\hline Low weight & 46 & 8.6 & 8 & 3.7 & 38 & 11.9 & 34 & 10.2 & 9 & 6.3 & 3 & 5.3 & 0.12 \\
\hline No reply & 14 & 2.6 & 4 & 1.8 & 10 & 3.1 & 11 & 3.3 & 2 & 1.4 & 0 & 0.0 & \\
\hline Practices Physical Activity & & & & & & & & & & & & & \\
\hline Yes & 298 & 55.6 & 144 & 66.1 & 154 & 48.4 & 176 & 53.0 & 88 & 61.5 & 31 & 54.4 & \\
\hline No & 232 & 43.3 & 72 & 33.0 & 160 & 50.3 & 151 & 45.5 & 54 & 37.8 & 26 & 45.6 & 0.40 \\
\hline No reply & 6 & 1.1 & 2 & 0.9 & 4 & 1.3 & 5 & 1.5 & 1 & 0.7 & 0 & 0.0 & - \\
\hline Health Problems & & & & & & & & & & & & & \\
\hline No & 376 & 70.1 & 172 & 78.9 & 204 & 64.2 & 236 & 71.1 & 93 & 65.0 & 45 & 78.9 & \\
\hline Yes & 160 & 29.9 & 46 & 21.1 & 114 & 35.8 & 96 & 28.9 & 50 & 35.0 & 12 & 21.1 & 0.22 \\
\hline
\end{tabular}

Note: ${ }^{1}$ Four consumers did not answer this question; ${ }^{2}$ The Body Mass Index (BMI) $\leq 18.49 \mathrm{~kg} / \mathrm{m}^{2}$ was considered: low weight; $\mathrm{BMI} \geq 18.50$ and $\leq 24.99 \mathrm{~kg} / \mathrm{m}^{2}$ : eutrophic; BMI $\geq 25.00 \mathrm{~kg} / \mathrm{m}^{2}$ : and overweight (overweight and obesity) World Health Organization [35,36]. MV: Minimum Age. 
Table 2. Factors that influence the purchase of food, where to look for nutritional information, frequency and use of information and nutrition claims. Curitiba (PR), Brazil, 2018.

1 of 2

\begin{tabular}{|c|c|c|c|c|c|c|c|}
\hline \multirow{3}{*}{ Variable } & \multicolumn{6}{|c|}{ Participants } & \multirow{3}{*}{$p$-value } \\
\hline & \multicolumn{2}{|c|}{ Total $(n=536)$} & \multicolumn{2}{|c|}{ Female $(n=318)$} & \multicolumn{2}{|c|}{ Male $(n=218)$} & \\
\hline & $\%$ & $\mathrm{n}$ & $\%$ & $\mathrm{n}$ & $\%$ & $\mathrm{n}$ & \\
\hline \multicolumn{8}{|l|}{ Factors that influence the purchase of food ${ }^{1}$} \\
\hline Price & 79.9 & 428 & 81.8 & 260 & 77.1 & 168 & 0.18 \\
\hline Taste & 78.0 & 418 & 80.5 & 256 & 74.3 & 162 & 0.09 \\
\hline Expiration date & 40.1 & 215 & 42.8 & 136 & 36.2 & 79 & 0.13 \\
\hline Quantity in packaging & 39.4 & 211 & 40.3 & 128 & 38.1 & 83 & 0.61 \\
\hline Product ingredients & 36.6 & 196 & 44.7 & 142 & 24.8 & 54 & $<0.01^{*}$ \\
\hline Brand & 33.0 & 177 & 32.7 & 104 & 33.5 & 73 & 0.85 \\
\hline Nutritional information on the label & 26.5 & 142 & 28.0 & 89 & 24.3 & 53 & 0.34 \\
\hline Practicality & 6.2 & 33 & 5.7 & 18 & 6.9 & 15 & 0.56 \\
\hline \multicolumn{8}{|l|}{ Where to look for nutritional information on foods ${ }^{1}$} \\
\hline In the media (e.g.: TV. newspapers. internet. magazines) & 66.0 & 354 & 71.4 & 227 & 58.3 & 127 & $<0.01^{*}$ \\
\hline With friends and family & 26.3 & 141 & 28.0 & 89 & 23.9 & 52 & 0.28 \\
\hline $\begin{array}{l}\text { With health professionals (doctor. nutritionist. but not } \\
\text { limited to) }\end{array}$ & 24.4 & 131 & 28.3 & 90 & 18.8 & 41 & $0.01^{*}$ \\
\hline I don't know about this & 18.8 & 101 & 14.8 & 47 & 24.8 & 54 & $<0.01^{*}$ \\
\hline In books & 14.9 & 80 & 16.0 & 51 & 13.3 & 29 & 0.38 \\
\hline \multicolumn{8}{|l|}{ Frequency of using nutritional information on food labels ${ }^{2}$} \\
\hline Sometimes & 41.6 & 223 & 47.5 & 151 & 33.0 & 72 & \multirow{4}{*}{$<0.01^{*}$} \\
\hline Rarely & 33.2 & 178 & 31.1 & 99 & 36.2 & 79 & \\
\hline Ever & 14.7 & 79 & 14.2 & 45 & 15.6 & 34 & \\
\hline Never & 10.4 & 56 & 7.2 & 23 & 15.1 & 33 & \\
\hline \multicolumn{8}{|l|}{ Reason for not using nutritional information ${ }^{3}$} \\
\hline I don't care about the composition of the food I'm buying & 34.2 & 80 & 30.3 & 37 & 38.4 & 43 & \multirow{6}{*}{$0.05^{*}$} \\
\hline I have no patience to read & 29.5 & 69 & 30.3 & 37 & 28.6 & 32 & \\
\hline I don't understand the information & 20.1 & 47 & 25.4 & 31 & 14.3 & 16 & \\
\hline I don't have time to read & 6.8 & 16 & 4.9 & 6 & 8.9 & 10 & \\
\hline The letters are too small & 5.6 & 13 & 3.3 & 4 & 8.0 & 9 & \\
\hline No reply & 3.8 & 9 & 5.7 & 7 & 1.8 & 2 & \\
\hline \multicolumn{8}{|l|}{$\begin{array}{l}\text { Factors that motivate the use of nutritional information on } \\
\text { food labels }{ }^{4}\end{array}$} \\
\hline $\begin{array}{l}\text { I like to know what I am buying and consuming. because } \\
\text { I like to take care of my health }\end{array}$ & 35.8 & 108 & 33.2 & 65 & 40.6 & 43 & \\
\hline I have doubts about its composition & 32.1 & 97 & 33.2 & 65 & 30.2 & 32 & \\
\hline I'm on a diet & 12.6 & 38 & 10.7 & 21 & 16.0 & 17 & 0.23 \\
\hline Product purchase for the first time & 4.6 & 14 & 6.1 & 12 & 1.9 & 2 & \\
\hline I have a health problem that requires more care with food & 3.6 & 11 & 4.1 & 8 & 2.8 & 3 & \\
\hline No reply & 11.3 & 34 & 12.8 & 25 & 8.5 & 9 & \\
\hline \multicolumn{8}{|l|}{ Nutritional claims used when purchasing a product ${ }^{1}$} \\
\hline "Trans fat-free" & 42.5 & 228 & 49.1 & 156 & 33.0 & 72 & $<0.01^{*}$ \\
\hline "Source of vitamins and minerals" & 38.1 & 204 & 39.3 & 125 & 36.2 & 79 & 0.47 \\
\hline "Rich in fiber"/"Source of fibers" & 34.9 & 187 & 40.3 & 128 & 27.1 & 59 & $<0.01^{*}$ \\
\hline I don't use any nutrition claims & 24.4 & 131 & 19.2 & 61 & 32.1 & 70 & $<0.01^{*}$ \\
\hline "Lactose-free" & 13.6 & 73 & 17.6 & 56 & 7.8 & 71 & $<0.01^{*}$ \\
\hline "Gluten-free" & 10.8 & 58 & 11.3 & 36 & 10.1 & 22 & 0.65 \\
\hline \multicolumn{8}{|l|}{ Types of foods that usually use nutritional information ${ }^{1}$} \\
\hline Stuffed crackers and snacks & 45.0 & 241 & 46.9 & 149 & 42.2 & 92 & 0.287 \\
\hline Milk, cheese and yogurts & 42.0 & 225 & 46.5 & 148 & 35.3 & 77 & $0.01^{*}$ \\
\hline
\end{tabular}


Table 2. Factors that influence the purchase of food, where to look for nutritional information, frequency and use of information and nutrition claims. Curitiba (PR), Brazil, 2018.

2 of 2

\begin{tabular}{|c|c|c|c|c|c|c|c|}
\hline \multirow{3}{*}{ Variable } & \multicolumn{6}{|c|}{ Participants } & \multirow{3}{*}{$p$-value } \\
\hline & \multicolumn{2}{|c|}{ Total $(n=536)$} & \multicolumn{2}{|c|}{ Female $(n=318)$} & \multicolumn{2}{|c|}{ Male $(n=218)$} & \\
\hline & $\%$ & $\mathrm{n}$ & $\%$ & $\mathrm{n}$ & $\%$ & $\mathrm{n}$ & \\
\hline Canned food and sausage & 40.5 & 217 & 41.2 & 131 & 39.4 & 86 & 0.68 \\
\hline Breads and toast & 33.4 & 179 & 38.7 & 123 & 25.7 & 56 & $<0.01^{*}$ \\
\hline Diet and light products & 28.7 & 154 & 33.6 & 107 & 21.6 & 47 & $<0.01^{*}$ \\
\hline Other & 5.2 & 28 & 3.1 & 10 & 8.3 & 18 & $<0.01^{*}$ \\
\hline \multicolumn{8}{|c|}{$\begin{array}{l}\text { Most used nutritional information format printed on food } \\
\text { label }^{2}\end{array}$} \\
\hline Nutritional table & 63.6 & 341 & 64.5 & 205 & 62.4 & 136 & \\
\hline Explanatory images & 11.9 & 64 & 13.8 & 44 & 9.2 & 20 & \\
\hline Symbols and logos & 11.2 & 60 & 11.9 & 38 & 10.1 & 22 & $0.03^{*}$ \\
\hline Other & 1.1 & 6 & 0.9 & 3 & 1.4 & 3 & \\
\hline Do not use & 12.1 & 65 & 8.8 & 28 & 17.0 & 37 & \\
\hline
\end{tabular}

Note: "Significance from the Chi-Square test ( $p$-value $<0.05$ ), according to gender, from valid responses; ${ }^{1}$ The person could check more than one alternative as an answer; ${ }^{2}$ The person should only point out one alternative as an answer; ${ }^{3}$ This question was answered only by those who indicated the frequency of never or rarely in relation to the frequency of use of the nutritional information on food labels; ${ }^{4}$ This question was answered only by those who indicated the frequency of sometimes or always in relation to the frequency of use of nutritional information on food labels.

There was no statistical difference between the frequency of use of nutritional information with the nutritional status $(p=0.34)$ nor with the health problems of the respondents $(p=0.58)$ (Table 3). However, it was observed that, individuals who practiced physical activities used more the food label nutrition information $(p=0.04)$.

Regarding the use of nutritional claims, low weight individuals used more the claim "source of vitamins and minerals" ( $p=0.01)$, as well as, people with health problems, used more the claim "lactose-free" ( $p<0.01)$ (Table 3).

Regarding the use of nutritional information, depending on the type of product to be purchased, overweight and obese individuals used that information more to buy diet and light products $(p=0.02)$ than individuals with low weight, while the use of nutritional information when purchasing milk, cheese and yogurt was more common among those with health problems $(p<0.01)$ (Table 3) and those who practice physical activity ( $p=0.01)$.

Regarding confidence in the information printed on food labels, 61.9\% ( $n=332)$ trusted, $26.7 \%(n=143)$ believed that it depended on the food, 10.6\% $(n=57)$ did not trust the information and $0.7 \%(n=4)$ did not answer the question. Most of the suspicions involved the lack of credibility in the companies that produce the food (Table 4).

There was no relationship between confidence in the nutritional information printed on the food labels and the sociodemographic data, and the health of the participants (Table 1) and with the use of nutrition labeling ( $p=0.82$ ) (Table 5 ). However, $45.8 \%$ of the people who said they trusted nutritional information did not use it when purchasing food. When considering the use of the nutritional claim "rich in fiber", it was found that those who trusted this information used the information more than those who did not $(p<0.01)$, indicating that although they used the claim to select the product this was possibly made with caution (Table 2 ). 
Table 3. Relationship between the use of information and nutritional claims, with nutritional status and health problems. Curitiba (PR), Brazil, 2018.

\begin{tabular}{|c|c|c|c|c|c|c|c|c|c|c|c|}
\hline \multirow{3}{*}{ Variable } & \multicolumn{6}{|c|}{ Nutritional Status } & \multicolumn{5}{|c|}{ Health Problems } \\
\hline & $\begin{array}{l}\text { Low weight } \\
\qquad(n=46)\end{array}$ & \multicolumn{2}{|c|}{$\begin{array}{c}\text { Eutrophic } \\
(n=361)\end{array}$} & \multicolumn{2}{|c|}{$\begin{array}{l}\text { Overweight } \\
\quad(n=115)\end{array}$} & \multirow{2}{*}{$p$-value } & \multicolumn{2}{|c|}{$\begin{array}{c}\text { Yes } \\
(n=160)\end{array}$} & \multicolumn{2}{|c|}{$\begin{array}{c}\text { No } \\
(n=376)\end{array}$} & \multirow[t]{2}{*}{$p$-value } \\
\hline & $\%$ & $\mathrm{n}$ & $\%$ & $\mathrm{n}$ & $\%$ & & $\mathrm{n}$ & $\%$ & $\mathrm{n}$ & $\%$ & \\
\hline
\end{tabular}

Frequency of using nutritional

information on food labels ${ }^{1}$

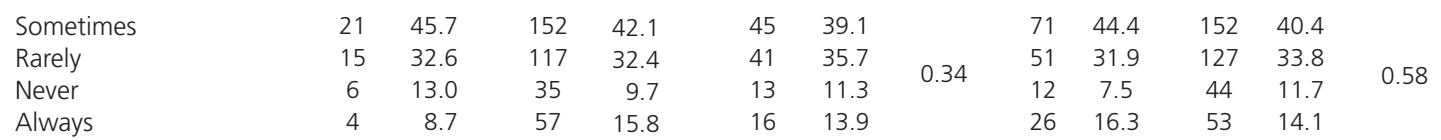

Nutritional claims used when purchasing a product ${ }^{2}$

\begin{tabular}{|c|c|c|c|c|c|c|c|c|c|c|c|c|}
\hline & & & & & & & & & & & & \\
\hline "Trans fat-free" & 26 & 56.5 & 146 & 40.4 & 50 & 43.5 & 0.11 & 67 & 41.9 & 161 & 42.8 & 0.84 \\
\hline minerals" & 25 & $54.3^{\mathrm{a}}$ & 139 & $38.5^{\mathbf{b}}$ & 34 & $29.6^{\mathbf{b}}$ & $0.01^{*}$ & 60 & 37.5 & 144 & 38.3 & 0.86 \\
\hline $\begin{array}{l}\text { "Rich in fibers" / "Source } \\
\text { of fibers" }\end{array}$ & 18 & 39.1 & 121 & 33.5 & 41 & 35.7 & 0.72 & 56 & 35.0 & 131 & 34.8 & 0.97 \\
\hline "Lactose-free" & 9 & 19.6 & 50 & 13.9 & 14 & 12.2 & 0.47 & 46 & 28.8 & 27 & 7.2 & $<0.01^{*}$ \\
\hline "Gluten-free" & 1 & 2.2 & 45 & 12.5 & 11 & 9.6 & 0.09 & 20 & 12.5 & 38 & 10.1 & 0.41 \\
\hline Other & 4 & 8.7 & 23 & 6.4 & 10 & 8.7 & 0.63 & 11 & 6.9 & 26 & 6.9 & 0.99 \\
\hline $\begin{array}{l}\text { I don't use any nutrition } \\
\text { claims }\end{array}$ & 6 & 13.0 & 94 & 26.0 & 27 & 23.5 & 0.15 & 32 & 20.0 & 99 & 26.3 & 0.12 \\
\hline $\begin{array}{l}\text { ypes of foods that usually } \\
\text { se nutritional information² }\end{array}$ & & & & & & & & & & & & \\
\hline $\begin{array}{l}\text { Stuffed crackers and } \\
\text { snacks }\end{array}$ & 27 & 58.7 & 160 & 44.3 & 49 & 42.6 & 0.15 & 76 & 47.5 & 165 & 43.9 & 0.44 \\
\hline Milk. cheeses and yogurts & 22 & 47.8 & 148 & 41.0 & 51 & 44.3 & 0.60 & 83 & 51.9 & 142 & 37.8 & $<0.01^{*}$ \\
\hline Canned food and sausage & 16 & 34.8 & 147 & 40.7 & 49 & 42.6 & 0.66 & 63 & 39.4 & 154 & 41.0 & 0.73 \\
\hline Breads and toast & 13 & 28.3 & 124 & 32.4 & 45 & 39.1 & 0.30 & 52 & 32.5 & 127 & 33.8 & 0.77 \\
\hline Diet and light products & 7 & $15.2^{\mathrm{b}}$ & 102 & $28.3^{\mathrm{ab}}$ & 42 & $36.5^{a}$ & $0.02^{*}$ & 46 & 28.8 & 108 & 28.7 & 0.99 \\
\hline Other & 1 & 2.2 & 20 & 5.5 & 7 & 6.1 & 0.59 & 10 & 6.3 & 18 & 4.8 & 0.49 \\
\hline I don't use any & 7 & 15.2 & 51 & 14.1 & 14 & 12.2 & 0.83 & 13 & 8.1 & 63 & 16.8 & $<0.01^{*}$ \\
\hline
\end{tabular}

Note: ${ }^{*} p$-value $<0.05 ;{ }^{1}$ The person should only point out one alternative as an answer; ${ }^{2}$ The person could check more than one alternative as an answer; Different letters in a row present results that are significantly different $(p<0.05)$.

Table 4. Reasons, categorized, mentioned by consumers who mentioned not having confidence in the nutritional information shown on food labels. Curitiba (PR), Brazil, 2018.

1 of 2

\begin{tabular}{|c|c|c|c|}
\hline \multirow{2}{*}{$\begin{array}{l}\text { Reasons for having no confidence in } \\
\text { nutrition label information }\end{array}$} & \multirow[t]{2}{*}{ Examples of consumers' statements ${ }^{*}$} & \multicolumn{2}{|c|}{$\begin{array}{c}\text { Number of } \\
\text { consumers }(n=200)^{* *}\end{array}$} \\
\hline & & $\mathrm{n}$ & $\%$ \\
\hline $\begin{array}{l}\text { Believe in the manipulation / alteration of } \\
\text { information by companies, for their own } \\
\text { benefit }\end{array}$ & $\begin{array}{l}\text { "Companies tend to manipulate information for their own interest" } \\
\text { "... I almost always think they manipulate data" } \\
\text { "You can lie to sell more" }\end{array}$ & 28 & 14.0 \\
\hline $\begin{array}{l}\text { Difficulty of interpretation, as the inform- } \\
\text { ation is not clear }\end{array}$ & $\begin{array}{l}\text { "Dividing portions on labels often makes it difficult" } \\
\text { "Sometimes the language used is very redundant and the consumer } \\
\text { ends up having confidence in something that he cannot even } \\
\text { understand" } \\
\text { "I am not aware of technical terminologies" }\end{array}$ & 27 & 13.5 \\
\hline
\end{tabular}


Table 4. Reasons, categorized, mentioned by consumers who mentioned not having confidence in the nutritional information shown on food labels. Curitiba (PR), Brazil, 2018.

Reasons for having no confidence in nutrition label information
Examples of consumers' statements*
Number of consumers $(n=200)^{* *}$

n $\%$

Believe that companies omit important information, for their own benefit, such as selling more product

"Most artificial and other industrialized foods do not describe the entire composition"

"There are products that still omit important information"

"Failure not to warn consumers"

"Some have false claims"

Do not believe all the information on the labels

"The information posted is not always completely reliable"

"Not all information on labels is true"

Lacks confidence in the methods / "Quantification method

references used to compose nutrition "I don't know where the information is coming from"

labeling

"Because there may be fluctuations in the data"

"I don't trust the food industry, I don't believe in industrial honesty"

Lack of confidence in the food industry "I don't trust the food industry very much"
"For the food industry, in many cases, they aim only at profit"

$15 \quad 7.5$

"Because I believe they modify it to look more "healthy"

Appeal for healthy marketing

"Because labels can be manipulated to look healthy"

"I believe they want to show something healthy and it is not"

"It actually depends on the brand"

Confidence depends on the brand / "There are unreliable brands"

company

"I always try to buy products from small / local brands because I

don't believe large corporations to be reliable"

"Some foods have trans fat, for example, below the label. Therefore,

They claim that information on the nutrition labeling (front or in the nutrition table) does not match the ingredient list or product type even though it is present in the composition, the label says 'trans fat free'"

"The composition of the food, does not match the one on the label, sometimes"

"The information in the nutritional table sometimes doesn't match the list of ingredients"

"I think the inspection is flawed"

"Inspection is not efficient"

"Because the inspection is doubtful"

They believe that Brazilian legislation on "Legislation is flawed"

labeling is flawed

"... I think RDC fails"

5

Believes that there may be an error in "I think there may be a production error" food production "Variation in large-scale production"

$4 \quad 2.0$

Do not believe due to reports of fraud "Due to possible fraud" and adulteration of products

"There are cases of adulteration of the product" 1 0.5

\begin{tabular}{lll}
\hline Ignoring the food's origin favors mistrust "Food's origin" & 0.5 \\
\hline Did not provide the reason *** & 7.5 \\
\hline
\end{tabular}

Note: *Three examples are exhibited when at least 10 consumers were mentioned, two examples when the mention was 2 to 9 consumers, and one example when the mention was made by a consumer; ${ }^{* *}$ This question was answered only by consumers who indicated that they trusted the nutritional information on the labels depending on the food $(n=143$ ) or that they did not trust the information ( $n=57)$. The question was descriptive and consumers could report more than one reason; ${ }^{* *}$ Consumers who answered that trust depended on the food, but did not mention the reason. 
Table 5. Use and confidence in the information presented on nutrition labeling. Curitiba (PR), Brazil, 2018.

\begin{tabular}{|c|c|c|c|c|c|c|c|}
\hline \multirow{3}{*}{ Variable } & \multicolumn{7}{|c|}{ Confidence in the information presented on nutrition labeling $(n=532)^{1}$} \\
\hline & \multicolumn{2}{|c|}{$\begin{array}{c}\text { Yes } \\
(n=332)\end{array}$} & \multicolumn{2}{|c|}{$\begin{array}{l}\text { Depends on the } \\
\text { food }(n=143)\end{array}$} & \multicolumn{2}{|c|}{$\begin{array}{c}\text { No } \\
(n=57)\end{array}$} & \multirow[t]{2}{*}{$p$-value } \\
\hline & $\%$ & $\mathrm{n}$ & $\%$ & $\mathrm{n}$ & $\%$ & $\mathrm{n}$ & \\
\hline \multicolumn{8}{|c|}{ Frequency of using nutritional information on food labels ${ }^{2}$} \\
\hline Sometimes & 43.1 & 143 & 42.7 & 61 & 31.6 & 18 & \multirow{4}{*}{0.82} \\
\hline Rarely & 34.9 & 116 & 30.1 & 43 & 31.6 & 18 & \\
\hline Always & 11.1 & 37 & 20.3 & 29 & 21.1 & 12 & \\
\hline Never & 10.8 & 36 & 7.0 & 10 & 15.8 & 9 & \\
\hline \multicolumn{8}{|c|}{ Nutritional claims used in the purchase of a food ${ }^{3}$} \\
\hline "Source of vitamins and minerals" & 40.7 & 135 & 35.7 & 51 & 29.8 & 17 & 0.23 \\
\hline "Trans fat-free" & 40.4 & 134 & 49.0 & 70 & 40.4 & 23 & 0.20 \\
\hline "Rich in fiber" / "Source of fibers" & 33.1 & $110^{\mathbf{b}}$ & 43.4 & $62^{\mathrm{a}}$ & 21.1 & $12^{c}$ & $<0.01^{*}$ \\
\hline "Lactose-free" & 13.0 & 43 & 15.4 & 22 & 12.3 & 7 & 0.74 \\
\hline "Gluten-free" & 9.9 & 33 & 9.8 & 14 & 19.3 & 11 & 0.10 \\
\hline Other & 3.9 & $13^{b}$ & 11.9 & $17^{\mathrm{a}}$ & 12.3 & $7^{a}$ & $<0.01^{*}$ \\
\hline I don't use any nutrition claim & 24.7 & 86 & 23.8 & 34 & 24.6 & 14 & 0.98 \\
\hline \multicolumn{8}{|c|}{ Types of foods that usually use nutritional information ${ }^{3}$} \\
\hline Stuffed crackers and snacks & 44.3 & 147 & 46.2 & 66 & 49.1 & 28 & 0.77 \\
\hline Milk, cheese and yogurts & 40.7 & 135 & 43.4 & 62 & 47.4 & 27 & 0.60 \\
\hline Canned food and sausage & 39.2 & 130 & 44.8 & 64 & 36.8 & 21 & 0.44 \\
\hline Breads and toast & 32.5 & 108 & 35.0 & 50 & 35.1 & 20 & 0.84 \\
\hline Diet and light products & 25.9 & 86 & 35.0 & 50 & 28.1 & 16 & 0.13 \\
\hline Others & 5.4 & 18 & 5.6 & 8 & 1.8 & 1 & 0.48 \\
\hline I do not use & 14.2 & 47 & 14.7 & 21 & 12.3 & 7 & 0.91 \\
\hline \multicolumn{8}{|c|}{$\begin{array}{l}\text { Nutritional information format present on the most used } \\
\text { food label }{ }^{2}\end{array}$} \\
\hline Nutritional table & 64.5 & 214 & 65.0 & 93 & 56.1 & 32 & \\
\hline Explanatory images & 12.7 & 42 & 7.7 & 11 & 17.5 & 10 & \\
\hline Symbols and logos & 10.2 & 34 & 13.3 & 19 & 12.3 & 7 & 0.32 \\
\hline Others & 0.6 & 2 & 1.4 & 2 & 3.5 & 2 & \\
\hline Do not use & 12.0 & 40 & 12.6 & 18 & 10.5 & 6 & \\
\hline
\end{tabular}

Note: "Significance from the chi-square test ( $p$-value $<0.05)$, according to gender, from valid responses; ${ }^{1}$ Four consumers did not answer this question; ${ }^{2}$ The person should only point out one alternative as an answer; ${ }^{3}$ The person could check more than one alternative as an answer; Different letters in a row present results that are significantly different $(p<0.05)$.

\section{DISCUSSION}

Many consumers used the nutritional information available on food labels, especially women. The interest in reading this information was also observed in other studies $[17,38]$ and may be associated with an increase in the population's interest in health benefits through food, especially among young adult consumers, such as university students [39]. Studies show that these individuals are increasingly concerned with health, and use the means of communication for seeking information on food and nutrition $[40,41]$, in addition to the information displayed on labels as a way of taking care of health $[11,42,43]$.

In this sense, interest in health and easy access to information may justify the fact that most students seek information about nutrition labeling through the media. This result was also found in 
other studies $[39,44]$, and demonstrates the importance of television, newspapers, the internet and magazines as a source of information, as they play a fundamental role in the search for knowledge as a basis for healthier food choices.

On the other hand, a significant portion of consumers reported using little the information contained on labels, due to the lack of concern with the composition of the food they bought. This result is worrying, given that the participants had a good educational background, the majority being in the health sciences sector, in which they already have previous knowledge and greater interest on this subject, in addition to enjoying good socioeconomic conditions. Consequently, considering the profile of the students, a higher prevalence of food label nutrition information reading by the participants was expected, a fact that was not confirmed.

Among this audience that makes little use of label nutrition information, we highlight those who had some health problem, since, depending on the problem, dietary modifications and/ or selection of specific foods may be required, besides the nutrition information on the label that may contribute to the treatment of health. This is because food labeling is a tool that helps in the population's food and nutrition education [45], helping consumers to choose healthier foods [46], thus contributing to disease prevention and control.

The relationship between having a health problem and using the food labeling was also observed by Sekiyama et al. [47], who, when interviewing 978 teachers in Brazil, with an average age of 41.5 years, found no difference between having a health problem (hypertension) and reading the food labels. However, it is important to point out that food is usually part of the non-pharmacological treatment of many health problems, so it would be important and necessary for these individuals to use the nutrition information contained on food labels more frequently to make more appropriate choices [48].

Other reasons mentioned to justify not using the food label nutrition information were lack of patience to read the label and understanding of the information presented. Such factors may be related to the illegibility of the nutrition information printed on the label, because if the information is not clear and readable to be understood by the majority of consumers, it may cause disinterest and lack of patience to read this information [49]. In addition, food labeling is the main link between the consumer and the product [8]. Therefore, there is a need to change the nutrition labeling in Brazil, so that it is possible to facilitate this communication and favor a better understanding and use of this dietary education instrument.

However, there are proposals to improve food labeling in the country following the example of Chile $[7,28]$, which aim to ensure clearer and more legible information on packaging, with an emphasis on the inclusion of warning labels, so that no misinterpretations occur, while promoting greater understanding, interest and motivation on the part of the population. These changes have already been well accepted by Brazilians [30].

With regard to nutritional claims, few students reported not using them at the time of purchase, demonstrating that the use of simple information on the front of the food package can influence the consumer's practice of buying food $[39,50]$. The use of claims may be associated to the fact that consumers use this information, thinking about the future consequences for their health [51]. Among these, the most used, especially among women, was the claim "trans fat-free". The high prevalence of the use of this claim evidences greater consumers' concern with the amount of fat present in food, and with the consumption of this type of fat that should be avoided [52-54] .At the same time, it is important to emphasize that, according to the Brazilian legislation regarding 
supplementary nutritional information, the use of the claim "trans fat-free" is permitted in products with a trans fat content less than or equal to $0.1 \mathrm{grams} /$ portion [10], even if the product has this substance among its Ingredients. Many consumers are unaware of this and may misinterpret this information reported on the food label, as this information ends up giving the false idea that they are not ingesting trans fat, regardless of the amount consumed [55].

When selecting the product, the calories followed by the list of ingredients constituted the information regarded as most important by consumers. This result suggests the concern of consumers in making healthy choices and seeking less caloric foods. The list of ingredients is of fundamental importance in the food labeling, as it displays the items that make up the product. Based on this information, consumers can identify the presence of elements, which is indicated as absent in the front labeling, as in the case of trans fat [56], or errors in the information of the nutritional table [57] (e.g.: products that indicate high protein content, per serving, but which have few protein ingredients), as well as that information contributes to the identification of processed and ultraprocessed foods, which should have a restricted consumption.

The interest in calories is almost similar to other studies $[43,47]$ and it possibly stems from health issues or is due to aesthetic standards determined by society. This may also explain the fact that eutrophic and overweight consumers use more the nutritional information to purchase light and diet products, as it is common to consider these foods as being less caloric than traditional foods, even though they do not always meet this reality $[58,59]$.

Additionally, in the present study, it was found that the interviewees who trusted the label nutritional information, did not use that information, while those who did not trust it reported using the information. The confidence in the nutritional information, even if not using it, may be associated with consumers having not gone through negative experiences and being aware of problems related to the information on food labels. This is because negative experiences directly influence consumer's distrust [60]. In this sense, it may be observed that there may be a relationship between the experiences observed by individuals and their confidence, and the explanation lies in the fact that the less negative experiences are perceived by the individual, the more confident he/she is in relation to the information of the products [61]. However, it is important to emphasize that it is unlikely for consumers in this study to go through negative experiences with the use of food label nutrition information, or will perceive a problem if they do not use and seek more information on the subject.

In addition, the fact of not trusting, but using the nutritional information on the labels, shows that people use that information, however with caution, possibly because they consider the information important. In addition, the fact that they use the food label nutrition information even if they do not trust it, may be related to the role of the university in contributing to the critical reflective thinking of students, as well as a greater access to information.

The lack of confidence occurred mainly due to distrust in the food industry, affecting the belief in the nutrition information that was presented [49]. Many consumers believed in adulterated information (or manipulated information), so that the food company would benefit therefrom; they believed that many companies omitted important information from food labels, aiming at larger product sales; and perceived the use of marketing, with a healthy appeal, when in fact a product was not. Other consumers, on the other hand, mentioned just not trusting the food industry, and so they did not have confidence in the label of their products or they believed that trusting the label depended on the brand (or manufacturer) of the product. The lack of confidence in the industry was also reported by Australian consumers [62], when considering the food label information. 
It is thus observed that consumers distrust is directly related to the marketing strategies used by the manufacturers, as well as the inaccurate and incorrect nutrition information exhibited on the food labels. An investigation carried out by the Subsecretaria de Vigilância, Fiscalização Sanitária e Controle de Zoonoses (Secretariat of Surveillance, Sanitary Inspection and Zoonosis Control) of the municipality of Rio de Janeiro [57], reinforces the fact that food labels present unsatisfactory information, as well as incorrect data that can induce consumers to make mistakes, such as purchasing foods with different nutritional contents than stated on the label, or buying a product with no indication of an allergenic ingredient when there is one. These data indicate the importance of Government inspection and of penalties imposed when so provided by law [58].

Finally, although the study was carried out with a sample of a considerable number of consumers, and achieved its objective, it has some limitations. The fact that the investigation was carried out only in the city of Curitiba, with students from a public university, and a large participation of health sciences students may not reflect the reality of consumers from other locations, with different knowledge and education level.

Additionally, although self-reported weight and height has been indicated as a good reference standard for nutritional status in many studies, its use may be considered a limitation by some professionals. In addition, the investigation was carried out using a non-probabilistic sample, and the extrapolation of the data should be performed with caution. Despite this, the results are relevant and essential for understanding the subject, as well as to reinforce the importance of the need for changes in nutrition labeling in Brazil, as well as to address priority research subjects for the management of the PNAN.

\section{CONCLUSION}

Food labels nutritional information was mostly used by women and physical activity practitioners; however, this use is not very frequent. The main reason for using nutritional information was to know what the respondents were buying and consuming, since they were keen at taking care of their health. On the other hand, the main reason for not using nutritional information was because the respondents were not concerned with the composition of the food they were buying.

Although a portion of consumers stated they trusted the nutritional information on the labels, often those who trusted did not use the information. In contrast, those who used the information more often was more suspicious of what was presented, indicating a more critical view about what was printed on the label. This lack of trust is damaging to the consumer, the State and the food industry.

Therefore, the results found can be used as a reference in the development of new research in this country, and assist in the strategies that have been adopted to reformulate the format of nutritional information on food labels. It also stresses that a clearer and more understandable labeling could contribute to improving consumers' confidence in the information that is presented, improving credibility in the food system and in the actions of the State to benefit the population health.

\section{A CKNOWLEDGEMENT}

We are grateful for the grant of the Programa Institucional de Bolsas de Iniciação Científica, Universidade Federal do Paraná, Tesouro Nacional (PIBIC UFPR TN, Institutional Scientific Initiation Scholarship Program, Federal University of Paraná, National Treasury) Scholarship to the author Lisane Moreno Lorena de Sousa, in the years 2017 to 2018. 
CO MEDEIROS, L STANGARLIN-FIORI and EH SELKE contribution to the conception and design. LML de SOUSA and F FURTADO contribution to data collection. CO MEDEIROS, LML de SOUSA, L STANGARLIN-FIORI, F FURTADO, and EH SELKE contribution to interpretation of data; elaboration of the article, critical review of intellectual content; final article approval.

\section{REFERENCES}

1. Monteiro CM, Cannon G, Levy R, Moubarac J-C, Jaime P, Martins AP, et al. NOVA: the star shines bright: Food Classification: Public Health. World Nutr. 2016 [cited 2019 Sept 18]; 7(1-3):28-38. Available from: https://worldnutritionjournal.org/index.php/wn/article/view/5

2. Monteiro CA, Moubarac J-C, Levy RB, Canella DS, Louzada MLDC, Cannon G. Household availability of ultra-processed foods and obesity in nineteen European countries. Public Health Nutr. 2018;21(1):18-26. http://dx.doi.org/10.1017/S1368980017001379

3. Otto MC, Afshin A, Micha R, Khatibzadeh S, Fahimi S, Singh G, et al. The Impact of dietary and metabolic risk factors on cardiovascular diseases and type 2 diabetes mortality in Brazil. Plos One. 2016;11(3):1-22. http://dx.doi.org/10.1371/journal.pone.0151503

4. Latasa P, Louzada MLDC, Martinez Steele E, Monteiro CA. Added sugars and ultra-processed foods in Spanish households (1990-2010). Eur J Clin Nutr. 2018;72(10):1404-12. http://dx.doi.org/10.1038/s41430-0 17-0039-0

5. Monteiro CA, Cannon G, Lawrence M, Costa Louzada ML, Pereira Machado P. Ultra-processed foods, diet quality, and health using the NOVA classification system. Rome: FAO; 2019 [cited 2019 Sept 18]. Available from: http://www.fao.org/3/ca5644en/ca5644en.pdf

6. Presidência da República (Brasil). Lei 8.078, de 11 de setembro de 1990. Dispõe sobre a proteção do consumidor e dá outras providências. Brasília; 1990 [citado 18 set 2019]. Disponível em: http://www. planalto.gov.br/ccivil_03/Leis/L8078.htm

7. Ministerio de Salud (Chile). Ley 20606, sobre composición nutricional de los alimentos y su publicidad. Santiago; 2012 [cited 2019 Sept 18]. Available from: https://www.leychile.cl/Navegar?idNorma=1041570

8. World Health Organization. Food and Agriculture Organization of the United Nations. Codex Alimentarius: food labelling. 5th ed. Roma: Organization; 2007 [cited 2019 Sept 18]. Available from: http://www.fao.org/ docrep/pdf/010/a1390e/a1390e00.pdf

9. Ministério da Saúde (Brasil). Agência Nacional de Vigilância Sanitária. Resolução da Diretoria Colegiada - RDC n 360, de 23 de dezembro de 2003. Dispõe sobre o Regulamento Técnico sobre Informação Nutricional de Alimentos e Bebidas. Brasília: Diário Oficial da União; 2003.

10. Ministério da Saúde (Brasil). Agência Nacional de Vigilância Sanitária. Resolução da Diretoria Colegiada - RDC $n^{\circ}$ 54, de 12 de novembro de 2012. Dispõe sobre o Regulamento Técnico sobre Informação Nutricional Complementar. Brasília: Diário Oficial da União; 2012.

11. Merwe DV, Bosman M, Ellis S. Consumers' opinions and use of food labels: results from an urban - rural hybrid area in South Africa. Food Res Int. 2014;63(Part A):100-7. http://dx.doi.org/10.1016/j.foodres.2014.03.032

12. Christoph MJ, Loth KA, Eisenberg ME, Haynos AF, Larson N, Neumark-Sztainer D. Nutrition facts use in relation to eating behaviors and healthy and unhealthy weight control behaviors. J Nutr Educ Behav. 2018;50(3):267-74. http://dx.doi.org/10.1016/j.jneb.2017.11.001

13. Mhurchu CN, Eyles H, Jiang Y, Blakely T. Do nutrition labels influence healthier food choices? Analysis of label viewing behaviour and subsequent food purchases in a labelling intervention trial. Appetite. 2018;121(1):360-5. http://dx.doi.org/10.1016/j.appet.2017.11.105

14. Drichoutis AC, Lazaridis P, Nayga Junior RM, Kapsokefalou M, Chryssochoidis G. A theoretical and empirical investigation of nutritional label use. Eur J Health Econ. 2007;9(3):293-304. http://dx.doi.org/10.1007/ s10198-007-0077-y

15. Draper AK, Adamson AJ, Clegg S, Malam S, Rigg M, Duncan S. Front-of-pack nutrition labelling: are multiple formats a problem for consumers? Eur J Public Health. 2010;23(3):517-21. http://dx.doi.org/10.1093/ eurpub/ckr144 
16. Graham DJ, Jeffery, RW. Predictors of nutrition label viewing during food purchase decision making: an eye tracking investigation. Public Health Nutr. 2011;15(2):189-97. http://dx.doi.org/10.1017/S1368980011 001303

17. Chopera P, Chagwena DT, Mushonga NG. Food label reading and understanding in parts of rural and urban Zimbabwe. Afr Health Sci. 2014;14(3):576-84. http://dx.doi.org/10.4314/ahs.v14i3.12

18. Edge MS, Toner C, Kapsak WR, Geiger CJ. The impact of variations in a fact-based front-of-package nutrition labeling system on consumer comprehension. 2014;114(6):843-54. http://dx.doi.org/10.1016/j. jand.2014.01.018

19. Hess R, Visschers VH, Siegrist M. The role of health-related, motivational and sociodemographic aspects in predicting food label use: a comprehensive study. Public Health Nutr. 2011;15(3):407-14. http://dx.doi. org/10.1017/S136898001100156X

20. Mclean R, Hoek J, Hedderley D. Effects of alternative label formats on choice of high-and low-sodium products in a New Zealand population sample. Public Health Nutr. 2012;15(5):783-91. http://dx.doi. org/10.1017/S1368980011003508

21. Méjean C, Macouillard P, Péneau S, Hercberg S, Castetbon K. Perception of front-of-pack labels according to social characteristics, nutritional knowledge and food purchasing habits. Public Health Nutr. 2013;16(3):392-402. http://dx.doi.org/10.1017/S1368980012003515

22. Feunekes GI, Gortemaker IA, Willems AA, Lion R, Van Den Kommer M. Front-of-pack nutrition labelling: testing effectiveness of different nutrition labelling formats front-of-pack in four European countries. Appetite. 2008;50(1):57-70. http://dx.doi.org/10.1016/j.appet.2007.05.009

23. Kimura A, Wada Y, Tsuzuki D, Goto S, Cai D, Dan I. Consumer valuation of packaged foods: interactive effects of amount and accessibility of information. Appetite. 2008;51(3):628-34. http://dx.doi.org/10.1016/j. appet.2008.05.054

24. Khandpur N, Swinburn B, Monteiro CA. Nutrient-based warning labels may help in the pursuit of healthy diets. Obesity. 2018;26(11):1670-1. http://dx.doi.org/10.1002/oby.22318

25. El Presidente de la República (Peru). Decreto Supremo que aprueba el Reglamento del Decreto Legislativo $n^{\circ}$ 1304, Decreto Legislativo que aprueba la Ley de Etiquetado y Verificación de los Reglamentos Técnicos de los Productos Industriales Manufacturados Lima; 2017 [cited 2019 Sept 18]. Available from: http://extwprlegs1. fao.org/docs/pdf/per174046.pdf

26. Ministerio de Salud Pública (Uruguay). Decreto n²72/018. Montevideo; 2018 [cited 2019 Sept 18]. Available from: https://www.gub.uy/ministerio-salud-publica/comunicacion/noticias/octogonos-para-etiquetado-dealimentos

27. Instituto Brasileiro de Defesa do Consumidor. Rotulagem de alimentos e doenças crônicas: percepções do consumidor no Brasil. São Paulo: Instituto; 2014 [citado 1 dez 2019]. Disponível em: http://www.idec.org.br/ pdf/rotulagem-de-alimentos-e-doencas-cronicas.pdf

28. Instituto Brasileiro de Defesa do Consumidor. Idec apresenta novo modelo de rotulagem nutricional à Anvisa. 2017 [citado 18 dez 2019]. Disponível em: https://idec.org.br/noticia/idec-apresenta-novo-modelo-derotulagem-nutricional-anvisa

29. Organização Pan-Americana da Saúde. Brasil dá importante passo para tornar mais claros rótulos de alimentos, avalia OPAS. Brasília: Organização; 2018 [citado 19 set 2019]. Disponível em: https://www.paho. org/bra/index.php?option=com_content\&view=article\&id=5683:brasil-da-importante-passo-para-tornarmais-claros-rotulos-de-alimentos-avalia-opas\&ltemid=839

30. Khandpur N, Mais LA, Sato PM, Martins APB, Spinillo CG, Rojas CFU. Choosing a front-of-package warning label for Brazil: a randomized, controlled comparison of three different label designs. Food Res Int. 2019;121(1):854-61. http://dx.doi.org/10.1016/j.foodres.2019.01.008

31. Ministério da Saúde (Brasil). Sumário executivo: prioridades de pesquisa para a gestão da Política Nacional de Alimentação e Nutrição. Brasília; 2017 [citado 19 set 2019]. Disponível em: http://189.28.128.100/dab/ docs/portaldab/documentos/sumario_executivo_agenda_pesquisa.pdf

32. Dean AG, Sullivan KM, Soe MM. OpenEpi: Open source epidemiologic statistics for public health. 2013 [cited 2019 Sept 16]. Available from: https://www.openepi.com/SampleSize/SSPropor.htm

33. Monteiro RA, Coutinho JG, Recine E. Usage of food and beverage labels by supermarket shoppers in Brasilia, Brazil. Rev Panam Salud Publica. 2005;18(3):172-7. http://dx.doi.org/10.1590/s1020-49892005000800004 
34. Gagné C, Godin G. Les théories sociales cognitives: guide pour la mesure des variables et le développement de questionnaire. Québec: Bibliothèque Nationale; 1999 [cited 2020 Mar 20]. Available from: https:// pdfs.semanticscholar.org/0e2b/2f92f199f9f6939fb7b0bde04c80856ca90e.pdf?_ga=2.146362 484.199535933.1588027248-1799964732.1588027248

35. World Health Organization. Physical status: the use of and interpretation of anthropometry, report of a WHO expert committee. Geneva: Organization; 1995 [cited 2019 Sept 19]. Available from: http://www.who.int/ iris/handle/10665/37003

36. World Health Organization. Obesity: preventing and managing the global epidemic. report of a who consultation. Geneva: Organization; 2000 [cited 2019 Sept 19]. Available from: https://www.who.int/ nutrition/publications/obesity/WHO_TRS_894/en/

37. Statsoft Inc. Statistica: data analysis software system. Version 7. Tulsa, USA. 2004.

38. Viola GCV, Bianchi F, Croce E, Ceretti E. Are food labels effective as a means of health prevention? J Public Health Res. 2016;5(3):139-42. http://dx.doi.org/10.4081/jphr.2016.768

39. Madilo FK, Owusu-Kwarteng J, Kunadu APH, Tano-Debrah K. Self-reported use and understanding of food label information among tertiary education students in Ghana. Food Control. 2020;108(1):106841. http:// dx.doi.org/10.1016/j.foodcont.2019.106841

40. Vaterlaus JM, Patten EV, Roche C, Young JA. \#Gettinghealthy: the perceived influence of social media on Young adult health behaviors. Comput Hum Behav. 2015;45(1):151-7. http://dx.doi.org/10.1016/j. chb.2014.12.013

41. Sidani JE, Shensa A, Hoffman B, Hanmer J, Primack BA. The association between social media use and eating concerns among US young adults. J Acad Nutr Diet. 2016;116(9):1465-72. http://dx.doi.org/10.1016/j. jand.2016.03.021

42. Asioli D, Aschemann-Witzel J, Caputo V, Vecchio R, Annunziata A, Næs T, et al. Making sense of the "clean label" trends: a review of consumer food choice behavior and discussion of industry implications. Food Res Int. 2017;99(Part1):58-71. http://dx.doi.org/10.1016/j.foodres.2017.07.022

43. Yardimci H, Koç N. Do food labels affect Turkish consumers' nutritional choices and expectations? Prog Nutr. 2019;21(1):59-66. http://dx.doi.org/10.23751/pn.v21i1.6405

44. Marzarotto B, Alves MK. Leitura de rótulos de alimentos por frequentadores de um estabelecimento comercial. Cien Saude. 2017;10(2):102-8. http://dx.doi.org/10.15448/1983-652X.2017.2.24220

45. Nascimento C, Raupp SMM, Townsend RT, Balsan GA, Minossi V. Conhecimento de consumidores idosos sobre rotulagem de alimentos. Rev Epidemiol Control Infect. 2013 [citado 16 set 2019];3(4):144-7. Disponível em: http://www.ppgcardiologia.com.br/wp-content/uploads/2014/05/Conhecimento-de-consumidores-idosossobre-rotulagem-de-alimentos.pdf

46. Veríssimo AC, Barbosa MCA, Almeida NAV, Queiroz ACC, Kelmann RG, Silva CLA. Association between the habit of reading food labels and health-related factors in elderly individuals of the community. Rev Nutr. 2019;32:e180207. http://dx.doi.org/10.1590/1678-9865201932e180207

47. Sekiyama FM, Rodrigues $R$, Mesas $A E$, González $A D$, Andrade SM. Reading the Nutritional Information on Food Labels Among Teachers with and without Hypertension in Brazil. Int J Prev Med. 2019;10(1):1-6. http:// dx.doi.org/10.4103/ijpvm.IJPVM_40_18

48. Lindmann IL, Silva MT, Cesar JG, Mendoza-Sassi, RA. Reading food labels among users of primary care and associated factors. Cad Saude Colet. 2016;24(4):478-86. http://dx.doi.org/10.1590/1414-462x20 1600040234

49. Marins BR, Jacob SC, Peres F. Avaliação qualitativa do hábito de leitura e entendimento: recepção das informações de produtos alimentícios. Food Sci Tech. 2008;28(3);579-85. http://dx.doi.org/10.1590/S0101-2 0612008000300012

50. Kleef EV, Dagevos $\mathrm{H}$. The growing role of front-of-pack nutrition profile labeling: a consumer perspective on key issues and controversies. Crit Rev Food Sci Nutr. 2015;55(3):291-303. http://dx.doi.org/10.1080/104083 98.2011 .653018

51. Tórtora G, Ares $\mathrm{G}$. Influence of time orientation on food choice: case study with cookie labels. Food Res Int. 2018;106(1):706-11. http://dx.doi.org/10.1016/j.foodres.2018.01.045

52. World Health Organization. Global strategy on diet, physical activity and health. Geneva: Organization; 2004. 
53. World Health Organization. Follow-up to the political declaration of the high-level meeting of the General Assembly on the Prevention and Control of Non-communicable Diseases: Sixty-sixth World Health Assembly. Geneva: Organization; 2013.

54. OrganizaçãoPan-AmericanadaSaúde. Américaslivres degordurastrans. RiodeJaneiro:Organização;2008[citado 18 set 2019]. Disponível em: https://www.abia.org.br/vsn/temp/z2017929AsAmericasLivresdeGordurasTrans. pdf

55. Pinto ALD, Miranda TLS, Ferraz VP, Athayde DD, Salum A. Determinação e verificação de como a gordura trans é notificada nos rótulos de alimentos, em especial naqueles expressos "0\% gordura trans". Braz J Food Tech. 2016;19:e2015043. http://dx.doi.org/10.1590/1981-6723.4315

56. Kliemann N, Kraemer MVS, Silveira BM, González-Chica DA, Proença RPC. Tamanho da porção e gordura trans: os rótulos de alimentos industrializados brasileiros estão adequados? Demetra. 2015;10(1):43-60. http://dx.doi.org/10.12957/demetra.2015.12981

57. Casemiro L, Luques I. Mais de $60 \%$ dos rótulos de alimentos no Rio têm problemas de informação. Rio de Janeiro: O Globo; 2018 [citado 18 set 2019]. Disponível em: https://oglobo.globo.com/economia/defesa-doconsumidor/mais-de-60-dos-rotulos-de-alimentos-no-rio-tem-problemas-de-informacao-22568651

58. Marins BR, Araújo IS, Jacob SC. A propaganda de alimentos: orientação, ou apenas estímulo ao consumo? Cienc Saude Coletiva. 2011;16(9):3873-82. http://dx.doi.org/10.1590/S1413-81232011001000023

59. Lohn SK, Eskelsen MW, Ramos RJ. Avaliação do conhecimento sobre produtos diet e light por funcionários e universitários de instituição de ensino superior. Hig Aliment. 2017 [citado 16 set 2019];31(264/265):30-7. Disponível em: http://docs.bvsalud.org/biblioref/2017/03/832657/264-265-sitecompressed-30-37.pdf

60. Flanagan $P$, Johnston $R$, Talbot D. Customer confidence: the development of a "pre-experience" concept. Int J Serv Ind Manag. 2005;16(4):373-84. http://dx.doi.org/10.1108/09564230510614013

61. Lee J, Dan Lee H. Does satisfaction affect brand loyalty? Acad Mark Stud J. 2013;17(2):133-47.

62. Tonkin E, Webb T, Coveney J, Meyer SB, Wilson AM. Consumer trust in the Australian food system e the everyday erosive impact of food labelling. Appetite. 2016;103(1):118-27. http://dx.doi.org/10.1016/j. appet.2016.04.004 